UDC 622.276 .3

A. M. Matviienko, Cand. Sc. (Tech.), Assoc. Prof., orcid.org/0000-0002-9081-9030,

V. M. Savyk, Cand. Sc. (Tech.), orcid.org/0000-0002-0706-0589, P. O. Molchanov, Cand. Sc. (Tech.), orcid.org/0000-0001-5335-4281
DOI: $10.29202 /$ nvngu/2018-3/2

Poltava National Technical Yuri Kondratyuk University, Poltava, Ukraine, e-mail: novator11977@ukr.net; savicppntu@ rambler.ru; petja_men@ukr.net

\title{
MULTILEVEL SYSTEM OF MAGNET AND THERMAL DEPARAFINIZATION WITH EXTERNAL INSULATING COATINGS
}

Purpose. Explaining the design, composition and principles for determining the multilevel magnet and thermal deparafinization complex, which is located in the oil well, improves the mining of layer fluid with high content of asphalt-resin-paraffin deposits (ARPD) by heating and magnetizing it at specified intervals and is equipped with external insulating coatings.

Methodology. The methodical basis of the conducted studies is the analysis and consideration of the literature used and positive experience of preventing asphalt-resin-paraffin deposits during mining of hydrocarbons with high content of asphalt-resin-paraffin deposits using engineering analysis and results evaluation.

Findings. The result of the research is the substantiation of the design of a multilevel complex of magnet and thermal deparafinization and its elements, which are integrated into the structure of the lift from pump-compressor pipes and are equipped with external insulating coatings. There has been explained an analytical model for calculation of parameters of operation of multilevel deparafinization complex equipped with insulating coatings.

Originality. For the first time there has been produced an exploitation model of multilevel complex of magnet and thermal deparafinization and methods for determining key parameters of the developed complex.

Practical value. There has been shown and explained an analytical model for calculating the power consumption parameters of the developed multilevel magnet and thermal deparafinization complex and the level of magnetic moment of fluid flow elements in the lift of pump-compressor pipes equipped with such a system. There has been suggested a design of the magnet and thermal deparafinizator and material for manufacturing external insulating coatings of elements of such complex.

Keywords: asphalt-resin-paraffin deposits, the magnet and thermal activation, the deparafinizator, pump-compressor pipes, an insulting coating

Introduction. Mining of liquid hydrocarbons is often complicated by the presence of paraffins or asphalt-resin-paraffinic additives in them, which cause the formation of asphalt-resin-paraffinous deposits in the inner cavity of the pump-compressor pipes. Over time, deposits, which are hydrocarbons methane from $\mathrm{C}_{16} \mathrm{H}_{34}$ to $\mathrm{C}_{64} \mathrm{H}_{130}$, silica gel resins, asphalt-resinous compounds, hydrates, and others worsen and in some cases make it impossible to mine liquid products, since over time they close the passage section of the pump-compressor pipes.

Various means [1] are used to prevent adhesion of sediments on the walls of the equipment: they include thermal, chemical, physical means and their combination. Special equipment, magnetic devices, chemical diluents, heaters, and others are used for it.

One of the most common types of equipment for liquidation of asphalt-resin-paraffin deposits is mobile steam generating units that heat the column of the pump-compressor pipes by pumping the heated dry steam into the well for the purpose of dilution of harmful impurities. The method is simple and versatile, but is characterized by high consumption of diesel fuel for deparafinization and necessity in most cases, for stopping the production of hydrocarbon products.

Looking at the disadvantages of the method and the lack of a sufficient variety of technological equipment

(C) Matviienko A. M., Savyk V. M., Molchanov P. O., 2018 for other ways to eliminate asphalt-resin-paraffin deposits, due to their high cost, low reliability and the need to use a large variety of machines and devices during their use, the important goal is to develop a modern effective liquidation complex of asphalt-resin-paraffinic impurities and advance a scientifically grounded model of application of the complex, which will allow determining the optimal ratios of structural and operational parameters of such complex at the design stage, and achieving the greatest efficiency of its exploitation.

Analysis of the results of research and publications. A number of works are devoted to the analysis and study of paraffin-forming factors and methods for their prevention [2]. The result of the research was the development and introduction of various ways to eliminate asphalt-resin-paraffin deposits and special equipment for their usage to manifacturing.

As the most promising means of asphalt-resin-paraffin deposit prevention [3], we distinguish between the use of magnetic devices for deparafinization (Fig. 1) and the use of equipment for electrical deparafinization (heating, induction) (Fig. 2). Such devices do not change the chemical composition of the formation fluid and do not cause harm to the environment, in most cases they are installed in an arbitrary interval of the lift pump-compressor pipes, they are also effective.

Magnetic deparafinizators are produced in the permanent mode. With the increase in the content of resins 


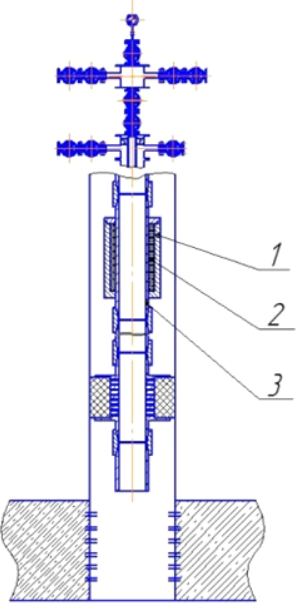

$a$

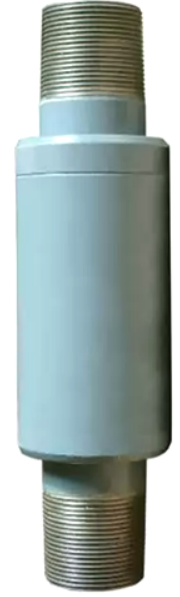

$b$
Fig. 1. Constructive components of the system of magnet deparafinization:

$a$ - the design of the lift of pump-compressor pipes equipped with magnet deparafinizator; 1 - magnet deparafinizator; 2 - the block of circulative permanent magnets; 3 - the pump-compressor pipe; $b$ - the magnet deparafinizator (general view)

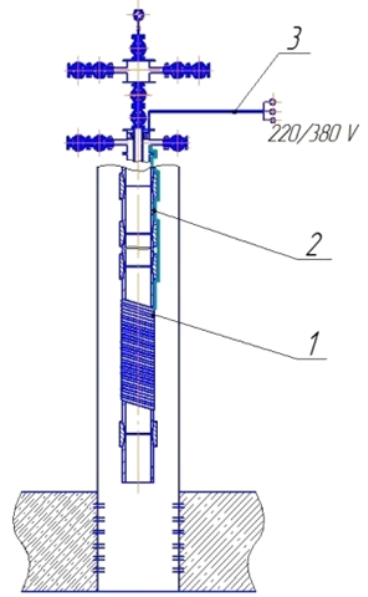

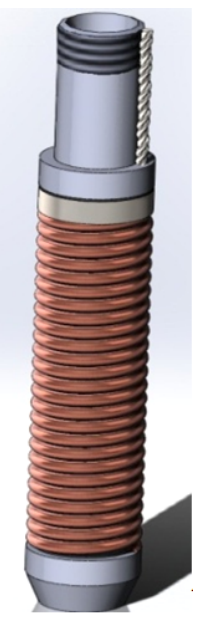

$b$
Fig. 2. Components of electrical deparafinization:

a-the design of the lift of pump-compressor pipes equipped with electric heater-deparafinizator; 1 - the heater; 2 - the lift of pump-compressor pipes; 3 - the electric cable; $b-$ the heater

and asphaltenes in the fluid, their influence on the fluid magnetization is more effective [4], as paraffin compounds have amagnetic properties. Unlike magnetic deparafinizators, electric heaters [5] are used in periodic and continuous modes, which allows regulating them depending on necessity.

According to studies [2], asphalt-resin-paraffin deposits begin on the interval from 1200-900 m down from the surface of the earth and up to the level of 100-150 $\mathrm{m}$ down the surface of the land along the length of the wellbore, which is explained by the positive conditions for anchoring on the interval. On this interval there is a need to use equipment to prevent asphalt-res- in-paraffin deposits along the length of the barrel pumpcompressor pipes.

In order to optimize the prevention of asphalt-resinparaffin deposits and increase usage efficiency of wells complexes Poltava National Technical University has created a multilevel system for heating the pump-compressor pipes (Fig. 3) based on pipe heaters [6].

The design and principle of the functioning of such a complex are characterized by the following [7]:

- it is placed along the length of the interval of occurrence of asphalt-resin-paraffin deposits;

- it has an electric supply, which allows operating it in constant and periodic modes;

- it is installed permanently in the lift of pump-compressor pipes, as part (pipe electric heaters and cable are installed by analogy with the installation of electro-centrifugal pumps);

- it is characterized by a similar principle of operation (direct heating by electric heating devices); this allows simplifying the design and reducing the cost;

- it has multilevel arrangement of heaters up to 3 (3-6-9-12), according to the number of cables veins unified with the cable of electro-centrifugal pumps installation (3 veins), it allows uniform heating of the formation fluid over the interval of anchoring;

- it is used both in the composition of the fountain lift of the oil and gas well and in conjunction with the pumping methods of oil production;

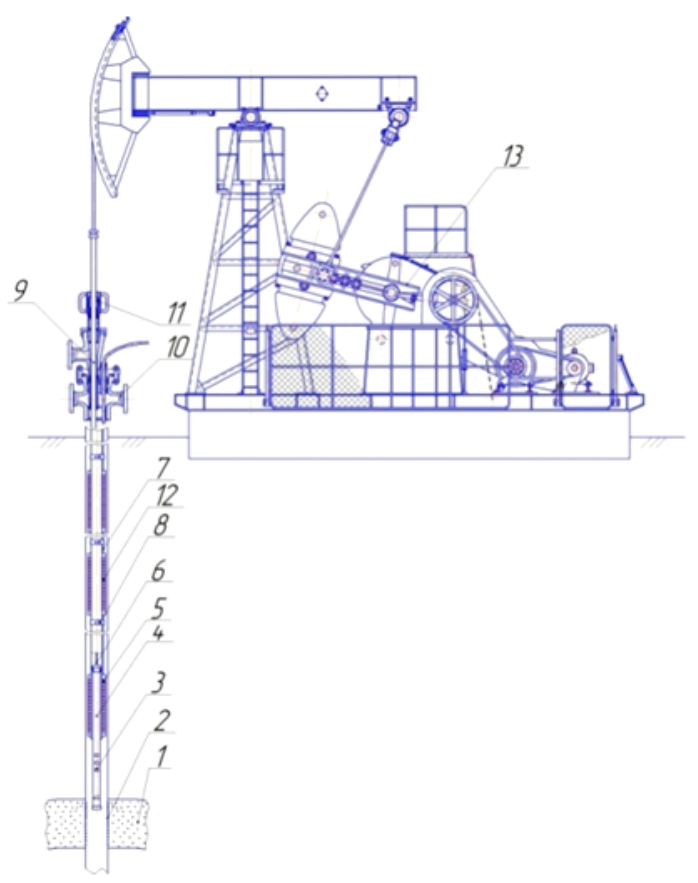

Fig. 3. The multilevel system of heating the lift of pumpcompressor pipes in the composition of well suckerrod pump set made basing on pipes heaters:

1 - the layer; 2 - perforation zone; 3 - universal gas and sand anchor; 4 - the pump; 5, 12 - deep pipes heaters; 6 - the column of rods; 7 - the cable; 8 - the clamp; $9-$ the polished stock; 10 - mining equipment; 11 - the loop, 13 - the rocking machine 
- it has the highest degree of unification with existing equipment.

A large number of advantages point to the prospect of a system of asphalt-resin-paraffin deposit prevention; however, its level of energy consumption (up to $90 \mathrm{~kW} / \mathrm{h}$ ) and significant losses of heat energy through the walls of pump-compressor pipes and casing columns are pushing for further scientific and engineering and designing works on improving multilevel systems of deposits liquidation.

An urgent issue is combination of operational and structural advantages of the most promising ways of asphalt-resin-paraffin deposit prevention and their introduction into multilevel complex, which will have a large degree of unification and simplicity of construction, and have the overwhelming number of imperfections; it is inherent to existing structures of such equipment.

Objectives of the article. The incomplete filling of the market of oil and gas industry equipment with complexes to prevent asphalt-resin-paraffin deposits, and a current tendency towards the introduction of combined technological complexes, determine the task for the authors to design and research the efficiency of operation of a multilevel complex of prevention of asphalt-resinparaffin deposits, which is made on the basis of magnet and electric devices (magnet and thermal deparafinizators), which is permanently attached to the lifts of pump-compressor pipes, will allow the constant or periodic dispensing of products with their use; there will be a possibility to use them in complexes to reduce the level of asphalt-resin-paraffin deposits on the walls of equipment that is pumped by pipelines, will have a greater level of unification with existing equipment and high labor efficiency. The design of developed multilevel complex of deposit prevention should enable placement of magnet and thermal deparafinizators in the zone with high level of such deposits.

Presentation of the main research and explanation of scientific results. According to the results of the studies shown in [2] and at production enterprises, asphalt-resin-paraffin deposits originate on intervals of $900-1000 \mathrm{~m}$ (in some cases from $1200 \mathrm{~m}$ ), which is explained by positive conditions: the temperature decrease of the fluid to $17-20{ }^{\circ} \mathrm{C}$, de-gassing on this interval, decrease in pressure, and others. Depth of deposits layer on the inner walls of pump-compressor pipes can reach a level of $30 \mathrm{~mm}$ and more - until the closure of the passage section of the lift. At this interval there is a need to use equipment to prevent this situation or the deposits that have occurred.

In order to improve the production of fluid mining with high content of asphalt-resin-paraffin deposits there has been substantiated a design, composition and principles of determination of the multilevel complex of magnet and thermal deparafinization by heating and magnetization at specified intervals.

The authors suggest consideration of the design, the principle of work and the calculation of the multilevel system of magnet and thermal deparafinization, which is made on the basis of magnet and thermal deparafinizators (Fig. 4).

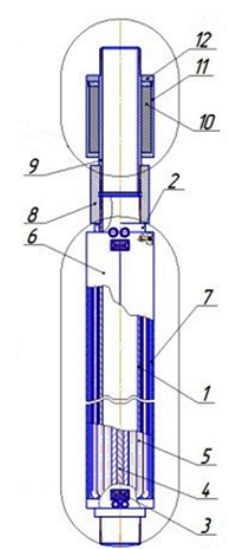

$a$

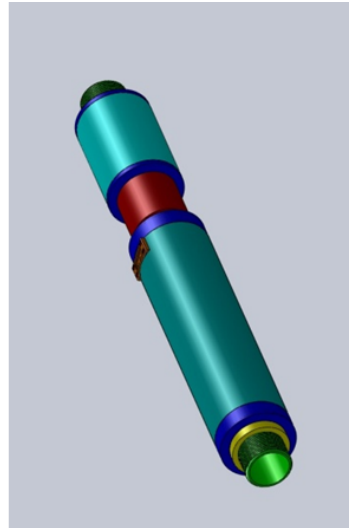

$b$
Fig. 4. The design of pipe magnet and thermal deparafinizator:

$a$ - assembled design; 1 - the shell; 2 - the puck; 3 - the nest; 4 - the cable; 5 - the heating element; 6 - external coating; 7 - the insulating coating; 8 - the connecting coupling clutch; 9 - the shell of magnet deparafinizator; 10 the constant longitudinal magnet; 11 - the shell of magnet block; 12 - the lid; $b$-general view of magnet and thermal deparafinizator

The magnet and thermal deparafinizator consists of the main functional elements: the pipe heater and the magnetic deparafinizator, resonated by the connecting coupling pipe coupling (Fig. 4).

The calculating scheme for work parameters of multilevel complex for preventing asphalt-resin-paraffin deposits, based on magnet and thermal deparafinizators is shown in Fig. 5.

The shell of the pipe heater (Fig. 4) is a pipe, fitted with threaded shanks on both sides for connection with connecting clutches 8 from pump-compressor pipes and its parts. The heating element 5 is a high resistance current conductor made from a nichrome wire located in sand or magnesium oxide (electrical insulating conductor), which is located in a refractory coating that is enclosed along the longitudinal axis of the pipe shell. The heating element 5 is fixed to the pipe shell 1 with the puck 2 . The pipe shell has plug nests 3 , which allow the cable to be taken to and out. The plug nests contain drainage for the heating element 5 , and are connected with each other by an electric cable 4 , the veins are located in a thermosetting hood. For the safety of the heating element 5 from the negative effect of the external factors, the external coating 6 is placed between the heating element 5 and the insulating coating 7 , which minimizes the heat loss from the work of the pipe heater.

In the pipe magnet and thermal deparafinizator, a magnetic deparafinizator is attached to the pipe heater with the help of connecting clutches 8 (Fig. 4); the magnetic deparafinizator consists of the shell 9, which is equipped with threaded shanks on both sides for connection of pipe connecting clutches 8 with pump-compressor pipes. On the external surface of the shell 9 there is a shell of the magnet block 11. Between them there are constant longitudinal magnets 10. They are clamped with the lid 12 . 


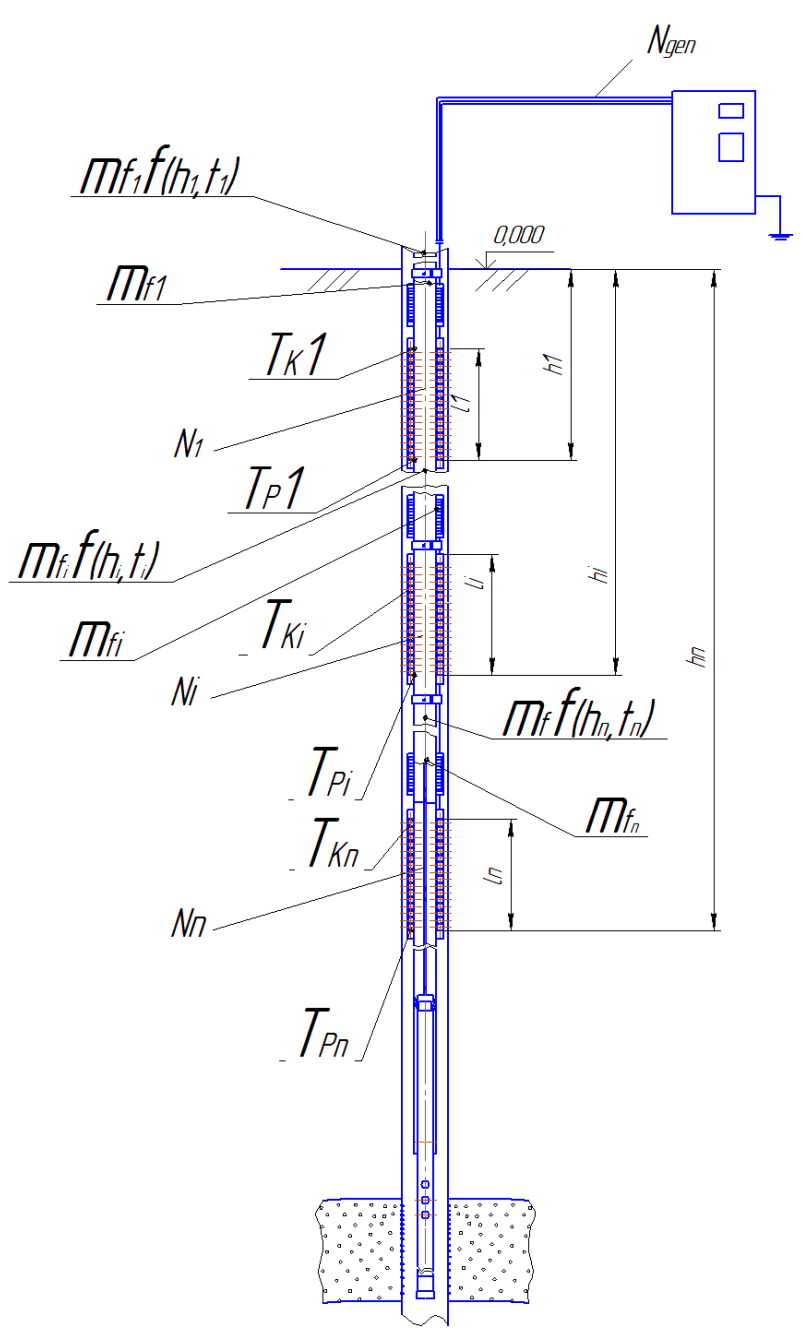

Fig. 5. The calculating scheme for work parameters of multilevel complex for preventing asphalt-resin-paraffin deposits, based on magnet and thermal deparafinizators for their quantity $i=1$...n:

$T_{P i}$ - the temperature on the input to the $i$ - deparafinizator; $T_{K i}$ - the final temperature of layer fluid on the output of $i$-deparafinizator; $N_{i}$ - power being consumed $i$ - heater of the deparafinizator; $l_{i}$ - the value of $i$-heater of the magnet and thermal deparafinizator; $M_{f i}$ - the value of magnet moment of volume unit of the layer fluid on the output of magnet and thermal deparafinizator; $M_{f i} f\left(h_{i}, t_{i}\right)$ - the value of magnet moment of volume unit of the layer fluid in the end of the $i$-area of activation; $N_{\text {gen }}$ - power of ground electricity substation

The work of the pipe magnet and thermal deparafinizator (Fig. 4) is performed in the following way. The device is installed as part of the lift of pump-compressor pipes, in the interval there are observed asphaltresin-paraffin deposits. On the external surface of pump-compressor pipes there is a cable 4 that gives energy to the heating element 5 and connects to the heater through the nest 3 . The fluid containing oil, water and connection, has a direction vertically tubing, comes in the inner part of the pipe magnet and thermal deparafinizator. During the movement of the inner part of the pipe heater there is an increase in the fluid temperature to the parameters at which the activation of molec- ular movements and dilution occurs. In the future, the product falls into the inner part of the magnetic deparafinizator, which is subject to re-magnetization. After heating in the pipe heater and the motion of the inner cavity of the magnetic deparafinizator in the fluid, there occurs a phenomenon of ferritization - the creation of ferromagnetic centers of internal crystallization, which are determined by a certain magnitude of the magnetic moment and become the basis [8].

During the passage of the fluid through the lift of pump-compressor pipes there is a decrease in the temperature and the magnetic moment obtained by them in the magnet and thermal deparafinizator. In order to restore the parameters to the lift several intervals have been included, at the beginning of them there are located magnet and thermal deparafinizators. This placement principle allows realizing an increase in fluid at steady regimes in preventing asphalt-resin-paraffin deposits, in which the value of the magnetic moment and the level of ferritization of the elements are within the range of optimum to minimize asphalt-resin-paraffin deposits.

In contrast to the multilevel heating complex of the lift of pump-compressor pipes, in this complex, made on the basis of magnet and thermal deparafinizators, the level of energy consumption will decrease, as heaters are the distribution of heat along the length of the lift in the range of $70-85^{\circ} \mathrm{C}$, and the individual heating of layer fluid in the magnet and thermal deparafinizator - up to $60-70{ }^{\circ} \mathrm{C}$ for the purpose of activation of the system of ferritization and creation of centers, which flow through a fluid flow.

Subsequently located on the length of the lift of pump-compressor pipes magnet and thermal deparafinizators have the role of deparafinizators of the system of ferritization. The heaters in the magnet and thermal deparafinizators allow using it both at periodic and permanent modes, while magnetic deparafinizators operate constantly.

The main characteristics of the developed multilevel complex of asphalt-resin-paraffin deposit prevention, made on the basis of magnet and thermal deparafinizators, are as follows:

- power required by the ground substation to supply the equipment, $N_{\text {gen }}, \mathrm{W}$;

- power used by the i-heater as part of the magnet and thermal deparafinizator in the process of thermal preparation of layer fluid, $N_{H}, \mathrm{~W}$;

- the value of the magnetic moment in the lift of pump-compressor pipes, $m_{f g e n}, \mathrm{~A} \cdot \mathrm{m}^{2}$;

- the coefficient of the heaters of magnet and thermal deparafinizators $\varepsilon$;

- geometric and weight characteristics of the elements, as well as the whole developed multilevel complex of asphalt-resin-paraffin deposit prevention.

The power required by the ground substation for the developed multilevel complex of asphalt-resin-paraffin deposit prevention, based on magnet and thermal deparafinizators, is

$$
N_{\text {gen }}=\sum_{i=1}^{n}\left(N_{i}+N_{k . e .}\right) \text {, }
$$


where $N_{i}$ is the power of an $i$-heater of pipe magnet and thermal deparafinizator, $\mathrm{W} ; N_{\text {k.e. }}$ is power decrease in the line of an $i$-heater of the pipe magnet and thermal deparafinizator, $\mathrm{W}$.

Power being used by an $i$-heater of the pipe magnet and thermal deparafinizator is

$$
N_{i}=\frac{c \cdot G_{i}\left(T_{K i}-T_{P i}\right)}{t_{i} \cdot \varepsilon_{i}},
$$

where $c$ is the heat capacity of layer fluid, $\mathrm{J} /(\mathrm{kg} \cdot \mathrm{Grad}$.); $G$ is the weight in the inner cavity of an $i$-heater of the pipe magnet and thermal deparafinizator

$$
G_{i}=\frac{\pi \cdot d_{v n}^{2} \cdot l_{p i} \cdot \rho_{p l . f .}}{4}
$$

where $d_{v n}$ is the inner diameter of the shell cavity of the pipe magnet and thermal deparafinizator, $\mathrm{m} ; l_{P i}$ is the size of an $i$-heater of the pipe magnet and thermal deparafinizator, $\mathrm{m} ; \rho_{p l . f}$ is density of layer fluid on the area of heating, $\mathrm{kg} / \mathrm{m}^{3} ; T_{K i}$ is the final temperature of layer fluid on the output of an i-heater, ${ }^{\circ} \mathrm{C} ; T_{P i}$ is the starting temperature of layer fluid on the input to an $i$-heater, ${ }^{\circ} \mathrm{C}$; $t_{i}$ is motion time of fluid flow of an $i$-heater; $\mathrm{s} ; \varepsilon$ is the coefficient of an $i$-heater of the pipe magnet and thermal deparafinizator.

Power decrease in the line of an $i$-heater of the pipe magnet and thermal deparafinizator is

$$
N_{k . e . i}=I_{i}^{2} R_{i},
$$

where $I_{i}$ is current in an $i$-heater of the pipe magnet and thermal deparafinizator, $\mathrm{A} ; R_{i}$ is resistance of the line of an $\mathrm{i}$-heater of the pipe magnet and thermal deparafinizator.

$$
R_{i}=\frac{r_{t i}}{s} \cdot l,
$$

where $S$ is the area of the section of line vein, $\mathrm{mm}^{2} ; l$ is the size of the line of an $i$-heater of the pipe magnet and thermal deparafinizator, $\mathrm{m} ; r_{t i}$ is the cable resistance during average temperature in the interval of disposal of an i-heater of the pipe magnet and thermal deparafinizator

$$
r_{t i}=r_{20}\left(1+a\left[T_{c . c b . i}-20\right]\right),
$$

where $r_{20}$ is resistance of the line material, $\mathrm{Om} \cdot \mathrm{mm}^{2} / \mathrm{m}$; $a$ is the coefficient of heat flow on the line resistance for $i$-material.

After summary consumed capacity, which has to be in ground substation for developed multilevel complex of asphalt-resin-paraffin deposit prevention, based on magnet and thermal deparafinizators, will be as follows

$$
N_{g e n}=\sum_{i=1}^{n}\left(\begin{array}{c}
\frac{c \cdot \pi \cdot d_{\vec{p} n}^{2} \cdot l_{l p f} \cdot \rho_{K i}\left(T_{P i}-T\right)}{4 \cdot t_{i} \cdot \varepsilon_{i}}+ \\
+\frac{I_{\vec{p}}^{2} \cdot r_{20}\left(1+a\left[T_{\text {s.sv. }}-20\right]\right) \cdot l}{s}
\end{array}\right) .
$$

The value of the magnetic moment in the lift of pump-compressor pipes in the interval of asphalt-resinparaffin deposits is defined

$$
m_{f \text { gen. }}=\frac{\sum_{3=1}^{n} m_{f i \text { gen. }}}{n},
$$

where $m_{f i g e n}$ is the average magnetic moment in the lift of pump-compressor pipes on the $i$-area, $\mathrm{A} \cdot \mathrm{m}^{2} ; n$ is the number of areas with magnetization of layer fluid.

The average magnetic moment in the lift of pumpcompressor pipes on the $i$-area is determined

$$
m_{f i \text { gen. }}=\frac{m_{f i .}+m_{f i . k}}{2}=\frac{m_{f i .}\left[1+k_{s c a t}\left(f\left(h_{i}, t_{i}\right)\right)\right]}{2} .
$$

We obtain,

$$
m_{f \text { gen. }}=\frac{\sum_{i=1}^{n} m_{f i .}\left[1+k_{\text {scat }}\left(f\left(h_{i}, t_{i}\right)\right)\right]}{2 \cdot n},
$$

where $k_{\text {scat }}$ is the coefficient of dispersion of the magnetic moment of flow elements of layer fluid that is the function from the distance being passed by it in the inner cavity of pump-compressor pipes and time, during which there was movement of layer fluid flow $-f\left(h_{i}, t_{i}\right)$.

For saving the optimal exploitative parameters of developed multilevel complex of asphalt-resin-paraffin deposit prevention, based on magnet and thermal deparafinizators there are such values as: $\varepsilon$ is the coefficient of heat loss of heaters of magnet and thermal deparafinizators; $k_{\text {scat }}$ is the coefficient of dispersion of the magnetic moment of flow elements of layer fluid.

The coefficient of heat loss of heaters of magnet and thermal deparafinizators is defined according to the equation

$$
\varepsilon=0.5\left(1+\left[1-\frac{R_{1}}{R_{2}}\right]\right),
$$

where $R_{1}$ is the coefficient of thermal conductivity of materials of the pipe shell, $\mathrm{W} /(\mathrm{m} \cdot \mathrm{K}) ; R_{2}$ is the coefficient of thermal conductivity of insulating coating together with external coating of the heater, $\mathrm{W} /(\mathrm{m} \cdot \mathrm{K})$.

The calculating scheme for determination of the coefficient of heat loss of heaters of magnet and thermal deparafinizators is shown in Fig. 6 and described with such an equation

$$
\begin{gathered}
R_{1}=a_{1} d_{2}+2 \frac{\lambda_{1}}{\ln \frac{d_{1}}{d_{2}}}+a_{2} d_{1} ; \\
R_{2}=a_{3} d_{3}+2 \frac{\lambda_{2}}{\ln \frac{d_{4}}{d_{3}}}+2 \frac{\lambda_{3}}{\ln \frac{d_{5}}{d_{4}}}+2 \frac{\lambda_{4}}{\ln \frac{d_{6}}{d_{5}}}+ \\
+2 \frac{\lambda_{5}}{\ln \frac{d_{7}}{d_{6}}}+2 \frac{\lambda_{6}}{\ln \frac{d_{8}}{d_{7}}}+a_{4} d_{8},
\end{gathered}
$$

where $a_{i}$ is the coefficient of thermal conductivity of materials of $i$-element, $\left.\mathrm{W} / \mathrm{mm}^{2} \cdot \mathrm{K}\right) ; d_{i}$ is the diameter of 


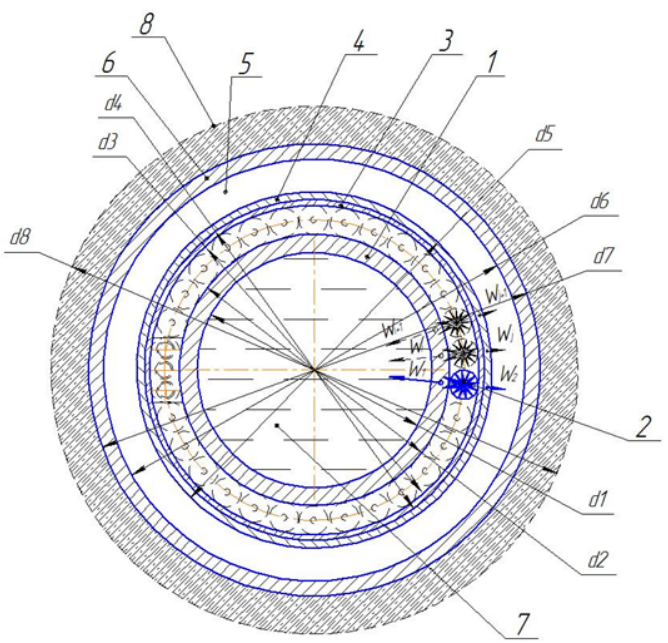

Fig. 6. The calculating scheme for the coefficient determination of heat loss of heaters of magnet and thermal deparafinizators:

1 - the shell; 2 - the heating element; 3 - the heat insulating coating; 4 - the external coating; 5 - intercolumn space; 6 - the creeping column; 7 - layer fluid; 8 - cementing zone; $d_{i}$ - diameter of decent part of the calculating model $(i=1-8) ; W_{i}$ - heat flow from heating elements $\left(W_{1}-\right.$ the part of heat flow, directed to the inner cavity of pump-compressor pipes); $W_{2}$ - the part of heat flow being lost externally

relevant element for the calculating scheme $(i=1-8), \mathrm{m}$; $\lambda_{i}$ is the coefficient of thermal conductivity of materials of $i$-element, $\mathrm{W} /(\mathrm{m} \cdot \mathrm{K})$.

The number of heaters, the power of each and the distance between them are selected on the condition of constant average temperature in the interval of the lift of pump-compressor pipes, where there are asphalt-resinparaffin deposits, higher than the laboratory found level of temperature of freezing deposits. According to the literature [5], the value $T_{\text {gen }}$ ranges from 60 to $76^{\circ} \mathrm{C}$.

With view of maintaining necessary level of the temperature and magnetic moment in the inner cavity of the column of pump-compressor pipes in the composition of multilevel complex of asphalt-resin-paraffin deposit prevention, based on magnet and thermal deparafinizators, it is offered to use external insulating coatings that are attached:

- on the external surface of pump-compressor pipes in the intervals between levels of magnet and thermal deparafinizators on the principle of attaching the cable electrical centrifugal submerged pumping systems;

- in heaters of magnet and thermal deparafinizators (Fig. 6) between heating elements 2 and the external coating 4.

Table shows the coefficients of heat loss through the parts of the developed multilevel complex of asphaltresin-paraffin deposit prevention, executed on the basis of magnet and thermal deparafinizators equipped with different types of external insulating coatings.

As the heat-holding ability is high and the minimum thickness of the layer, as a material for insulating coating for the developed multilevel complex of asphalt-resinparaffinous deposit prevention, is made on the basis of
Table

The coefficients values of heat loss through the parts of the developed multilevel complex of asphalt-resinparaffin deposit prevention, executed on the basis of magnet and thermal deparafinizators equipped with different types of external insulating coatings

\begin{tabular}{|c|c|c|}
\hline № & The construction type & 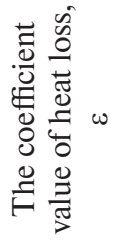 \\
\hline 1 & $\begin{array}{l}\text { Two layers of aluminum foil of } 0.5 \mathrm{~mm} \\
\text { with the layer of asbestos between them } \\
3.5 \mathrm{~mm}\end{array}$ & 0.85 \\
\hline 2 & $\begin{array}{l}\text { Two layers of aluminum foil of } 0.5 \mathrm{~mm} \text { with } \\
\text { the layer of mineral wadding between them } \\
3.5 \mathrm{~mm}\end{array}$ & 0.87 \\
\hline 3 & $\begin{array}{l}\text { Glass wool, covered with aluminum foil on } \\
\text { both sides - "Armofol }{ }^{\circledR "} \text { " to } 1 \mathrm{~mm}\end{array}$ & 0.88 \\
\hline 4 & $\begin{array}{l}\text { The list "K-SHIELD FIREWRAP", } \\
\text { metaling, } 4.5 \mathrm{~mm}\end{array}$ & 0.90 \\
\hline
\end{tabular}

magnet and thermal deparafinizators, it is suggested to use a heat-reflective insulating material, which is executed on the basis of glass wool, which is covered with aluminum foil - "Armofol ${ }^{\circledR}$ ". This material can withstand temperatures up to $+200^{\circ} \mathrm{C}$ and has high chemical and mechanical resistance. Moreover, this material has the ability to perceive magnetic and radiative illumination in the inner cavity of pipelines, which will allow the maximum magnetic moment to hold with particles of layer fluid from the magnet and thermal deparafinizators. This will minimize the number of magnet and thermal deparafinizators in the multilevel complex of asphalt-resin-paraffin deposit prevention.

The property that characterizes the operation efficiency of the developed complex is also $\eta_{b}$ - the percentage of extracted high-viscosity elements from the well space to the surface, which is determined by the formula

$$
\eta_{b}=\frac{\delta_{\text {arpdV }}}{\delta_{\text {arpd } G}} \cdot 100 \%,
$$

where $\delta_{\text {arpd } V}$ is the content of asphalt-resin-paraffin deposits on the output, $\mathrm{g} / \mathrm{dm}^{3} ; \delta_{\text {arpd } G}$ is the content of asphalt-resin-paraffin deposits on the mouth, $\mathrm{g} / \mathrm{dm}^{3}$.

The value $\delta_{\text {arpdi }}$ is defined by choosing relevant tests and implementing chromatographic analysis or using the filtration method.

The effective exploitation of developed multilevel complex of asphalt-resin-paraffin deposit prevention, based on magnet and thermal deparafinizators, is thought with provision of $\eta_{V}$ that approximates to 95-98\%.

The characteristics of multilevel complex of asphaltresin-paraffin deposit prevention, based on magnet and thermal deparafinizators, include the following: 
a) for a magnet and thermal deparafinizators: length $-9.5 \mathrm{~m}$; the size of pump-compressor pipes for the shell production $-89 \mathrm{~mm}$; external diameter of magnet and thermal deparafinizator $-130 \mathrm{~mm}$; the type of supply - alternating and direct current $220 / 380 \mathrm{~V}$; maximum temperature of layer fluid heating $-90{ }^{\circ} \mathrm{C}$ (nominal $-75^{\circ} \mathrm{C}$ ); power at maximum mode of layer fluid heating $-15-18.5 \mathrm{~kW}$;

b) for multilevel complex of asphalt-resin-paraffin deposit prevention, based on magnet and thermal deparafinizators: the spacing $-\mathrm{j} 1000 \mathrm{~m}$; the quantity of magnet and thermaldeparafinizators $-(3-6-9-12$ pcs.); the type of exploitation under voltage - constant/periodic.

The results of the research are as follows:

1. The design of multilevel complex of magnet and thermal deparafinization has been explained.

2. There the design of magnet and thermal deparafinizator, which is included in the multilevel complex of magnet and thermal deparafinization, has been projected and described.

3. The theoretical model for calculating the parameters of operation of the multilevel complex of magnet and thermal deparafinization, equipped with insulating coatings and its heat-magnetic demulsifiers has been explained.

4. Recommendations have been given on the use of materials for insulating coatings of multilevel complex of magnet and thermal deparafinization.

5. Technical characteristics of magnet and thermal deparafinizators and multilevel complex of asphalt-resin-paraffin deposit prevention, executed on their base, based on.

Recommendations further research. In further studies it is planned with the use of molecular spectroscopy to study the nature of the forces of adhesion component of asphalt-resin-paraffin deposits, in particular, the contribution of physical and chemical forces of nature and possible effects of partial polymerization in substance of asphalt-resin-paraffin deposits [9]. There will be considered analogue works [10], in which the methods of X-ray spectroscopy to identify N-ties, chemical ties and polymerized chemical structures in the hydrocarbon-mineral aggregates are elaborated.

\section{Conclusions.}

1. The production and usage of multilevel complex of magnet and thermal deparafinization, based on magnet and thermal deparafinizators, at the enterprise provides an opportunity to improve the effectiveness of asphalt-resin-paraffin deposit prevention during mining of hydrocarbons and its transportation by pipelines.

2. Developed designs of magnet and thermal deparafinizators allow using them together with exploitation of deep-pump machines and during exploitation of fountain oil well.

3. The projected design of multilevel complex of magnet and thermal deparafinization, based on magnet and thermal activators, will consume $45 . .50 \%$ less power than similar multilevel heating system of the lift of pump-compressor pipes, which realizes the principle of direct heating of wells.
4. The exploitation of offered multilevel complex of magnet and thermal deparafinization on the basis of magnet and thermal activators, gives the possibility to grant layer fluid such characteristics that it will be possible to prevent asphalt-resin-paraffin deposits even after getting fluid into the manifold.

5. The projected equipment allows using pipe magnet and thermal deparafinizators in the mode of switched on heaters as well as in the mode of magnetization without thermal preparation of layer fluid. The developed complex can be operated in periodic mode if it is necessary.

6 . The usage of multilevel complex of magnet and thermal deparafinization, based on magnet and thermal activators, gives the feasibility to reduce the deficiency of similar equipment in the markets of oil and gas industry countries.

\section{References.}

1. Stebelska, G. Ya., 2015. Geological conditions of exploration and development of deposits of highly viscous oil and natural bitumen. Visnyk Kharkivskogo natsionalnogo universytetu imeni V. N. Karazina, 1157, pp. 53-57. 2. Ivanova, L. V., Burov, E. A. and Koshelev, V. N., 2011. Asphalt-resin-paraffin deposits during mining, transportation and storage. Elektronniy nauchniy zhurnal “Neftegazovoe delo" [pdf], 1, pp. 268-284. Available at: $<$ http://www.ogbus.ru/authors/IvanovaLV/IvanovaLV_1.pdf> [Accessed 25 April 2017].

3. Sorokin, S.A. and Havkin, S. A., 2007. Peculiarities of physical and chemical mechanism of asphalt-resinparaffin formation in wells. Burenie i neft, 10, pp. 30-31. Available at: <http://burneft.ru/archive/issues/200710/11> [Accessed 20 April 2017].

4. Kopey, B. V., Martynets, O. R. and Stefanyshyn, A. B., 2014. Complement and properties of asphalt resinous stuff. Rozvidka ta rozrobka naftovyh i gazovyh rodovysch, 2(51), pp. 46-50.

5. Bysembayeva, K.T. and Muhambetyarova, A.N., 2014. The method of mining intensification of highly viscous oil with the usage of electric and thermal processing. Molodoy ucheniy, 7, pp. 111-115. Available at: <https://moluch.ru/archive/66/10982> [Accessed 11 April 2017].

6. Korobko, B.O., Matvienko, A.M. and Turzhanskiy, P. V., Poltava National Technical University, 2011. Deepwater electric heater. Ukraine. Pat. 63250. Available at: <http://uapatents.com/3-63250-glibinnijj-elektrichnijj-nagrivnik.html $>$ [Accessed 27 April 2017].

7. Matvienko, A. M., 2016. The substantiation of construction, peculiarities of assembling and calculating multilevel system of heating of reservoir products, conducted on the basis of "DTH" deep pipe heaters. Naukoviy byuleten natsionalnogo vydobuvnogo universytetu naukovogo i tehnichnogo zhurnalu, 3(153), pp. 54-60.

8. Korobko, B. O., 2016. Investigation of energy consumption in the course of plastering machine's work. Eastern-European Journal of Enterprise Technologies (Energy-saving technologies and equipment), 4(8(82)), pp. 4-11. Available at: <http://journals.uran.ua/eejet/ article/view/106873> [Accessed 11 March 2017].

9. Lyakh, M. M., Savyk, V. M. and Molchanov, P. O., 2017. Experimental and industrial research on foamgen- 
erating devices. Rozrobka korysnyh kopalyn. Naukovyi Visnyk Natsionalnoho Hirnychoho Universytetu, 5, pp. 17-23.

\section{Багаторівнева система магнітотеплової депарафінізації із зовнішніми ізолюючими кожухами}

\section{А. М. Матвієнко, В. М. Савик, П. О. Молчанов}

Полтавський національний технічний університет імені Юрія Кондратюка, м. Полтава, Україна, e-mail: novator11977@ukr.net; savicppntu@rambler.ru; petja_men@ ukr.net

Мета. Обгрунтування конструкції, складу й принципів визначення багаторівневого комплексу магнітотеплової депарафінізації, що розміщується в нафтовидобувній свердловині, поліпшує видобуток пластового флюїду з великим вмістом асфальто-смоло-парафінистих відкладень (АСПВ) шляхом підігрівання та намагнічування у визначених інтервалах і оснащується зовнішніми ізолюючими кожухами.

Методика. Методичною основою здійснених досліджень є комплексний аналіз і узагальнення використаної літератури, позитивного виробничого досвіду усунення асфальто-смоло-парафінистих відкладень під час видобутку вуглеводнів з підвищеним вмістом АСПВ із застосуванням експертного аналізу та оцінки отриманих результатів.

Результати. Результатом досліджень є обгрунтування конструкції багаторівневого комплексу магнітотеплової депарафінізації та її елементів, що інтегровані до складу підйомника з насосно-компресорними трубами (НКТ), і оснащені зовнішніми ізолюючими кожухами. Обгрунтована аналітична модель для розрахунку параметрів експлуатації багаторівневого комплексу депарафінізації, оснащеного ізолюючими кожухами.

Наукова новизна. Уперше розроблені модель експлуатації багаторівневого комплексу магнітотеплової депарафінізації та методика визначення параметрів розробленого комплексу.

Практична значимість. Обгрунтована та наведена аналітична модель для розрахунків показників споживаної потужності розробленого багаторівневого комплексу магнітотеплової депарафінізації та рівня магнітного моменту елементів потоку пластового флюїду в підйомнику НКТ, оснащеному такою системою. Описана конструкція магнітотеплового депарафінізатора та матеріал для виготовлення зовнішніх ізолюючих кожухів елементів комплексу.

Ключові слова: асфальто-смоло-парафінисті відкладення, магнітотеплова активація, депарафінізатор, насосно-компресорні труби, ізолюючий кожух

\section{Многоуровневая система магнитотепловой депарафинизации с внешними изолирующими кожухами}

\author{
А. М. Матвиенко, В. Н. Савик, П. А. Молчанов
}

Полтавский национальный технический университет имени Юрия Кондратюка, г. Полтава, Украина, е-mail: novator11977@ukr.net; savicppntu@rambler.ru; petja_men@ ukr.net

Цель. Обоснование конструкции, состава и принципов расчета многоуровневой системы магнитотепловой депарафинизации, которая размещается в нефтедобывающей скважине, улучшает условия добычи пластового флюида с высоким содержанием асфальто-смоло-парафинистих отложений (АСПО) путем его подогрева и намагничивания в заданных интервалах и оснащается внешними изолирующими кожухами.

Методика. Методической основой проведенных исследований является комплексный анализ и обобщение литературных источников, положительного промышленного опыта борьбы с асфальто-смоло-парафинистыми отложениями при добыче углеводородного сырья с повышенным содержанием АСПО с применением экспертного анализа и оценки полученных данных.

Результаты. Результатом исследований является обоснование конструкции многоуровневой системы магнитотепловой депарафинизации и ее отдельных элементов, которые интегрированы в состав подъемника с насосно-компрессорными трубами (HКТ) и оснащены внешними изолирующими кожухами. Обоснована расчетная модель для определения параметров работы многоуровневой системы депарафинизации, оснащенной изолирующими кожухами.

Научная новизна. Впервые разработаны модель работы многоуровневой системы магнитотепловой депарафинизации и методика расчета основных параметров разработанной системы.

Практическая значимость. Обоснована и приведена расчетная модель для определения показателей потребляемой мощности разработанной многоуровневой системы магнитотепловой депарафинизации и уровня магнитного момента элементов потока пластового флюида в подъемнике НКТ, который оснащен такой системой. Предложена конструкция магнитотеплового депарафинизатора и материал для изготовления внешних изолирующих кожухов элементов такой системы.

Ключевые слова: асфальто-смоло-парафинистые отложения, магнитотепловая активация, депарафинизатор, насосно-компрессорные трубы, изолирующий кожух

Рекомендовано до публікації докт. техн. наук B. С. Білецьким. Дата надходження рукопису 13.04.17. 